\title{
ANTIOXIDANT ENZYMES ACTIVITY AND LIPID PEROXIDATION IN SERUM, BREAST AND LEG MUSCLES OF BROILER CHICKENS REARED IN TWO DIFFERENT SYSTEMS AND EXPOSED TO ELEVATED AIR TEMPERATURE
}

\section{AKTYWNOŚĆ ENZYMÓW ANTYOKSYDACYJNYCH ORAZ PEROKSYDACJA LIPIDÓW W SUROWICY, MIĘŚNIACH PIERSIOWYCH I NÓG KURCZATT BROJLERÓW UTRZYMYWANYCH W DWÓCH SYSTEMACH ODCHOWU I PODDANYCH DZIAŁANIU PODWYŻSZONEJ TEMPERATURY POWIETRZA}

\author{
Department of Animal Physiology and Toxicology, Pedagogical University of Cracow, Poland \\ ${ }^{1}$ Department of Technology, Ecology and Economics of Animal Production, National Research \\ Institute of Animal Production, Balice, n. Kraków, Poland
}

\begin{abstract}
Streszczenie. Celem doświadczenia było zbadanie potencjalnych skutków stresu oksydacyjnego w surowicy, mięśniach piersiowych i nóg kurcząt brojlerów Ross 308, utrzymywanych w dwóch systemach odchowu w okresie letniej wysokiej temperatury powietrza. Kurczęta (400) przydzielono do dwóch grup (po 200 ptaków): I - ptaki utrzymywane w systemie ściołowym bez możliwości korzystania z wybiegów, II - kurczęta utrzymywane w systemie ściołowym z możliwością korzystania z wybiegów. Ptaki żywiono ad libitum standardowymi paszami sporządzonymi na bazie koncentratów. Ptaki przez cały okres doświadczenia miały swobodny dostęp do poideł z wodą. Obie grupy były utrzymywane w jednakowych warunkach środowiskowych (wilgotności, temperatury, programu świetlnego) oraz żywieniowych. W 6. tygodniu odchowu, w czasie wystąpienia letnich upałów, badano aktywność enzymów antyoksydacyjnych (SOD, CAT, GPx) oraz stężenie GSH i MDA w surowicy i mięśniach piersiowych i nóg. Dodatkowo krew i tkanki pobrano dzień przed wystąpieniem podwyższonej temperatury zewnętrznej. Wyniki wskazują, iż wysoka temperatura może indukować u kurcząt brojlerów stres oksydacyjny, niezależnie od systemu utrzymania, jednak kurczęta korzystające z zielonych wybiegów charakteryzowały się stabilniejszym systemem antyoksydacyjnym. Wysoka temperatura powietrza inicjuje peroksydację lipidów, na co wskazuje wzrost poziomu MDA, przy czym mięśnie nóg są bardziej wrażliwe na stres oksydacyjny niż mięśnie piersiowe.
\end{abstract}

Key words: rearing system, elevated air temperature, broiler chickens, meat, oxidative stress.

Słowa kluczowe: system utrzymania, podwyższona temperatura powietrza, kurczęta brojlery, mięso, stres oksydacyjny.

\section{INTRODUCTION}

Poultry meat is an extremely popular item, much sought after on the market. It is due to, among other things, its nutritional value, as poultry meat is a source of full-fledged animal protein (Woźniak et al. 2016). According to the FAO/WHO recommended standards (1990),

Corresponding author - Adres do korespondencji: Renata Muchacka, Department of Animal Physiology and Toxicology, Pedagogical University of Cracow, Podbrzezie 3, 31-054 Kraków, Poland, e-mail: rmuchacka@up.krakow.pl 
the biological value of chicken meat is equivalent to the value of milk protein. Apart from the nutritional value, poultry meat is selected as a component of meals due to its taste, short preparation time and relatively low price.

Poultry meat, compared to meat of other animal species, is characterized by a relatively low fat content, which determines its high dietary and nutritional values. At the same time, the lipids contained in this meat account for almost $70 \%$ of unsaturated fatty acids, including essential fatty acids (EFAs), i.e. linoleic acid in the amount of about $16 \mathrm{~g} \cdot 100 \mathrm{~g}^{-1}$ of fat, and a-linolenic acid $-3 \mathrm{~g} \cdot 100 \mathrm{~g}^{-1}$ of fat (Kitessa and Young 2009).

Unsaturated fatty acids (UFAs) have a beneficial effect on the human body, and the consumption of the recommended amount of EFAs can contribute to the reduction of the risk of coronary heart disease, diabetes, hypertension, arthritis, autoimmune diseases and cancers (Simopoulos 1999; Woźniak et al. 2016). At the same time, many authors (Pietrzak et al. 2005; Okafor et al. 2007; Okolie et al. 2009; Muchacka et al. 2016) point to the problem of lipid oxidation, which is particularly evident in products containing significant amounts of unsaturated fatty acids. High levels of PUFA in poultry fat adversely affect its stability. Rapid lipid oxidative changes and resulting products may reduce the quality characteristics of meat and poultry products and significantly reduce their storage life (Pikul 2009). This is confirmed by previous research (Pietrzak et al. 2005; Muchacka et al. 2016).

The quality of carcasses and poultry meat is shaped throughout the birds' life span, i.e. from breeding to slaughter. The selective breeding programs already decide on the anatomical composition of carcasses, the percentage of breast muscles and other muscles, as well as skin and fat. In turn, genetic predispositions, by appropriate nutrition and environmental conditions, can be properly utilized, influencing the positive qualities of meat, or - due to negligence - can lead to the production of poor quality meat.

Heat stress (HS) is one of the major problems in poultry production, especially in the countries of warm climates. High temperatures in poultry houses can cause hyperthermia in poultry. Its consequence is, among other things, increased mortality, immunosuppression, weight loss and laying, deterioration of meat and egg quality (El-Habbak et al. 2011; Zhang et al. 2012; Lara and Rostagno 2013). The size of losses in poultry flocks depends on many factors, including the age of birds, differences in temperature fluctuations, exposure times to elevated temperatures or ambient air humidity (El-Habbak et al. 2011; Zhang et al. 2012; Lara and Rostagno 2013).

The objective of the study was to determine the effect of the stress factor of the elevated air temperature a few days before the slaughter on the antioxidant enzyme activities (CAT, SOD, GPx) and glutathione (GSH) and malondialdehyde (MDA) concentration in serum, breast and leg muscles of broiler chickens, kept in two different rearing systems.

\section{MATERIAL AND METHODS}

The experiment was conducted in the summer production cycle (June/July 2014). It was performed on 400 Ross 308 hybrid broilers of both sexes. One-day-old broilers were randomly divided into two groups (200 birds per group), with five replicates (40 birds per subgroup): I - chicken kept on litter in an indoor system, II - birds kept on litter with access to 
green paddocks. Chickens in both groups were reared with a stocking density of 13 birds $\cdot \mathrm{m}^{-2}$, which did not exceed $33 \mathrm{~kg} \cdot \mathrm{m}^{-2}$ in accordance with the Rozporządzenie Ministra Rolnictwa i Rozwoju Wsi z dnia 15 lutego 2010 r., while $1 \mathrm{~m}^{2}$ of the green paddocks was assigned per bird. The paddocks were equipped with drinking nets and roofs to protect the chickens from the sun. The birds used the green paddocks from the first day of rearing at the hours of 7.00 to 20.00. Broiler chickens were fed ad libitum standard diets based on concentrates: starter diet (ME $12.5 \mathrm{MJ}$; CP 22\%) for the first 21 days, a grower diet (ME $13 \mathrm{MJ}$; CP 20.5\%) on days 22-35, and a finisher diet (ME 13 MJ; CP 20.5\%) on days 36-42. Throughout the study, birds had free access to water.

During the experiment, the data of temperature and humidity were collected outside and inside of the broiler house. The macroclimatic measurements were performed with the use of a Technoline Ltd climatic station: WS-3650-IT (Germany), which recorded data every 1 hour throughout the experimental period. Inside the broiler house the temperature and humidity were recorded on STIENEN BE's PL-9000 „poultry computer” (Netherlands). Microclimate sensors were placed in the zone occupied by the broiler chickens. In addition, at 8.00 and 13.00 , the temperature and humidity measurements were performed by the Testo 435 apparatus (Germany), at 3 points diagonally in each compartment (subgroup) and at 3 points diagonally in the paddock at the birds' level. The microclimatic data in Table 1 and Table 2 are the mean calculated from the data read from all the measuring devices. In the second rearing period, at high outdoor temperatures, which occurred in the 6th week of the experiment, on days 39 and 42 of the experiment, blood, breast and leg muscles were collected from 6 birds in each group to determine the activity of the antioxidant enzymes: superoxide dismutase (SOD), catalase (CAT) and glutathione peroxidase (GPx), and the level of reduced glutathione (GSH) and malondialdehyde (MDA). In addition, blood and tissue samples were collected on day 35 of the experiment, i.e. before high outdoor temperatures in the summer. Blood and organs were collected between 13.00 and 15.00 hours.

Table 1. The outdoor and the indoor air temperature from 28. to 42 . day of rearing Tabela 1. Temperatura powietrza wewnątrz brojlerni i na wybiegach od 28. do 42. dnia odchowu

\begin{tabular}{ccccccc}
\hline $\begin{array}{c}\text { Day of } \\
\text { rearing } \\
\text { Dzień }\end{array}$ & \multicolumn{3}{c}{$\begin{array}{c}\text { Indoor air temperature } \\
\text { Temperatura wewnątrz brojlerni }\left[{ }^{\circ} \mathrm{C}\right]\end{array}$} & \multicolumn{2}{c}{$\begin{array}{c}\text { Outdoor air temperature } \\
\text { Temperatura na wybiegach } \\
\text { odchowu }\end{array}$} & \multicolumn{2}{c}{ group I - grupa I } & group II - grupa II & \\
\cline { 2 - 6 } & 8.00 & 13.00 & 8.00 & 13.00 & 8.00 & 13.00 \\
\hline 28 & 20.5 & 22.5 & 21.4 & 22.7 & 21.15 & 21.7 \\
29 & 21.0 & 22.1 & 20.9 & 21.9 & 16.9 & 21.4 \\
30 & 21.6 & 22.4 & 21.9 & 21.7 & 20.7 & 24.0 \\
31 & 20.3 & 21.8 & 18.4 & 20.7 & 15.7 & 23.1 \\
32 & 20.7 & 24.3 & 21.3 & 23.2 & 19.8 & 25.9 \\
33 & 20.3 & 23.3 & 21.3 & 23.3 & 25.1 & 27.9 \\
34 & 21.4 & 24.5 & 20.9 & 22.8 & 19.0 & 26.3 \\
$28-34$ & 20.8 & 23.0 & 20.9 & 22.3 & 19.8 & 24.3 \\
35 & 21.4 & 21.9 & 20.9 & 23.3 & 19.1 & 26.3 \\
36 & 22.5 & 24.6 & 22.8 & 23.6 & 27.6 & 34.0 \\
37 & 22.6 & 24.5 & 23.0 & 23.6 & 27.8 & 32.6 \\
38 & 22.8 & 24.0 & 21.9 & 23.4 & 19.3 & 27.1 \\
39 & 21.4 & 27.7 & 21.4 & 25.8 & 24.8 & 34.1 \\
40 & 23.5 & 27.4 & 23.5 & 24.7 & 30.8 & 35.4 \\
41 & 23.4 & 28.0 & 22.1 & 26.3 & 22.6 & 32.2 \\
42 & 24.1 & 27.2 & 24.5 & 26.6 & 25.6 & 33.2 \\
$35-42$ & 22.7 & 25.7 & 22.5 & 24.7 & 24.7 & 31.9 \\
\hline
\end{tabular}


Table 2. The outdoor and the indoor air humidity from 28. to 42. day of rearing

Tabela 2. Wilgotność wewnątrz i na zewnętrz brojlerni od 28. do 42. dnia odchowu kurcząt brojlerów

\begin{tabular}{|c|c|c|c|c|c|c|}
\hline \multirow{3}{*}{$\begin{array}{l}\text { Day of } \\
\text { rearing } \\
\text { Dzień } \\
\text { odchowu }\end{array}$} & \multicolumn{4}{|c|}{$\begin{array}{c}\text { Indoor air humidity } \\
\text { Wilgotność wewnątrz brojlerni [\%] }\end{array}$} & \multirow{2}{*}{\multicolumn{2}{|c|}{$\begin{array}{l}\text { Outdoor air humidity } \\
\text { Wilgotność na wybiegach [\%] }\end{array}$}} \\
\hline & \multicolumn{2}{|c|}{ group I - grupa I } & \multicolumn{2}{|c|}{ group II - grupa II } & & \\
\hline & 8.00 & 13.00 & 8.00 & 13.00 & 8.00 & 13.00 \\
\hline 28 & 71 & 71 & 66 & 66 & 86 & 73 \\
\hline 29 & 71 & 70 & 77 & 70 & 90 & 76 \\
\hline 30 & 70 & 67 & 69 & 68 & 82 & 87 \\
\hline 31 & 69 & 65 & 69 & 62 & 93 & 55 \\
\hline 32 & 68 & 56 & 61 & 52 & 87 & 75 \\
\hline 33 & 69 & 59 & 62 & 53 & 84 & 40 \\
\hline 34 & 69 & 69 & 65 & 56 & 80 & 36 \\
\hline $28-34$ & 69.6 & 65.3 & 67.0 & 61.0 & 86.0 & 63.1 \\
\hline 35 & 68 & 66 & 66 & 60 & 77 & 76 \\
\hline 36 & 73 & 71 & 71 & 74 & 85 & 78 \\
\hline 37 & 73 & 70 & 70 & 77 & 89 & 80 \\
\hline 38 & 73 & 75 & 71 & 76 & 88 & 56 \\
\hline 39 & 75 & 62 & 71 & 62 & 87 & 35 \\
\hline 40 & 70 & 63 & 60 & 61 & 78 & 38 \\
\hline 41 & 65 & 63 & 61 & 62 & 73 & 41 \\
\hline 42 & 65 & 66 & 52 & 62 & 67 & 38 \\
\hline $35-42$ & 70.3 & 67.0 & 65.3 & 66.8 & 80.5 & 55.3 \\
\hline
\end{tabular}

Blood samples were taken from the vein wings (vena cutanea ulnaris) into tubes containing anticoagulant ( $2 \%$ sodium oxalate). The samples were centrifuged at $200 \mathrm{~g}$ for 5 minutes at $+4^{\circ} \mathrm{C}$; then the serum was removed immediately and stored at $-20^{\circ} \mathrm{C}$ until analyzed. Tissue specimens (breast and leg muscles) were rinsed with saline to remove the blood and then were homogenized.

The activity of SOD was marked according to the spectrophotometric cytochrome method by Rice-Evans et al. (1991). The CAT activity was estimated by measuring the breakdown of $\mathrm{H}_{2} \mathrm{O}_{2}$ at $240 \mathrm{~nm}$ according to the method of Aebi (1984). The activity of GPx was estimated by the modified method of Lück (1962). SOD, CAT and GPx activity in serum and tissues were expressed as $\mathrm{U} \cdot \mathrm{ml}^{-1}$ and $\mathrm{U} \cdot \mathrm{mg}^{-1}$ protein, respectively. The concentration of $\mathrm{GSH}$ was measured by an assay with the use of the dithionitrobenzoic acid recycling method described by Ellman (1959) and was expressed as $\mu \mathrm{mol} \cdot \mathrm{ml}^{-1}$ for serum and $\mu \mathrm{mol} \cdot \mathrm{g}^{-1}$ protein for muscles. Lipid peroxidation was assessed by measuring MDA formation, using the thiobarbituric acid (TBA) assay (Ohkawa et al. 1979). MDA concentrations in serum and muscles were expressed as $\mathrm{nmol} \cdot \mathrm{ml}^{-1}$ and $\mathrm{nmol} \cdot \mathrm{mg}^{-1}$ protein, respectively. Total protein concentration in the supernatants of homogenates of the breast and the leg muscles was determined according to the Bradford method (1976) with bovine serum albumin as the standard.

The results were analyzed statistically with Statistica ver. 10.0 PL (StatSoft Inc. 2011, USA). Significant differences between the experimental groups were verified by the analysis of variance and Duncan's multiple range test and considered significant at $P \leq 0.05$. The results were presented as the means and standard errors of the mean (SEM).

\section{RESULTS}

As the temperature increased, SOD and GPx activity (Table 3) and the serum level of MDA (Table 4) increased in both groups. However, statistically significant differences in SOD were reported only in group I between days 35 and $42(P \leq 0.01)$ and between 39 and 42 $(P \leq 0.05)$ days of rearing. In the case of GPx the differences were recorded in group I 
between days 35 and $42(P \leq 0.05)$ and in group II between days 35 and $39,42(P \leq 0.05)$. In addition, on the 42nd day of the experiment, statistically significant differences $(P \leq 0.05)$ were observed in the SOD and GPx activity between the studied groups. Statistically significant increase in serum MDA was observed in both groups on days $39(P \leq 0.05)$ and $42(\mathrm{P} \leq 0.01)$ compared to day 35 (Table 4).

Table 3. Antioxidant enzymes activity in serum

Tabela 3. Aktywność enzymów antyoksydacyjnych w surowicy

\begin{tabular}{|c|c|c|c|c|c|c|c|c|c|}
\hline \multirow{3}{*}{$\begin{array}{l}\text { Day of rearing } \\
\text { Dzień odchowu }\end{array}$} & \multicolumn{3}{|c|}{$\mathrm{SOD}\left[\mathrm{U} \cdot \mathrm{ml}^{-1}\right]$} & \multicolumn{3}{|c|}{ CAT $\left[\mathrm{U} \cdot \mathrm{ml}^{-1}\right]$} & \multicolumn{3}{|c|}{$\mathrm{GPx}\left[\mathrm{U} \cdot \mathrm{ml}^{-1}\right]$} \\
\hline & \multicolumn{2}{|c|}{$\begin{array}{l}\text { group } \\
\text { grupa }\end{array}$} & \multirow[t]{2}{*}{ SEM } & \multicolumn{2}{|c|}{$\begin{array}{l}\text { group } \\
\text { grupa }\end{array}$} & \multirow[t]{2}{*}{ SEM } & \multicolumn{2}{|c|}{$\begin{array}{l}\text { group } \\
\text { grupa }\end{array}$} & \multirow[t]{2}{*}{ SEM } \\
\hline & 1 & II & & 1 & II & & 1 & II & \\
\hline 35 & $0.831^{\mathrm{A}}$ & 0.618 & 0.261 & 55.57 & 81.19 & 14.68 & $36.60^{a}$ & $46.80^{a}$ & 5.34 \\
\hline 39 & $1.152^{\mathrm{a}}$ & 0.743 & 0.292 & 63.90 & 94.52 & 15.87 & 41.44 & $50.35^{a}$ & 5.76 \\
\hline 42 & $2.015^{\mathrm{Bb}}$ & $1.123^{*}$ & 0.345 & 57.56 & 66.71 & 13.43 & $54.79^{b^{*}}$ & $67.99^{b^{*}}$ & 4.22 \\
\hline
\end{tabular}

*Values in rows differ significantly - Wartości w wierszach różnią się statystycznie istotnie $(P \leq 0,05)$.

a, b values in columns with different letters differ significantly - wartości w kolumnach oznaczone różnymi literami różnią się statystycznie istotnie $(P \leq 0,05)$.

$A, B$ values in columns with different letters differ highly significantly - wartości w kolumnach oznaczone różnymi literami różnią się statystycznie wysokoistotnie $(P \leq 0,01)$.

Table 4. The level of GSH and MDA in serum

Tabela 4. Stężenie GSH i MDA w surowicy

\begin{tabular}{|c|c|c|c|c|c|c|}
\hline \multirow{3}{*}{$\begin{array}{l}\text { Day of rearing } \\
\text { Dzień odchowu }\end{array}$} & \multicolumn{3}{|c|}{$\mathrm{GSH}\left[\mu \mathrm{mol} \cdot \mathrm{ml}^{-1}\right]$} & \multicolumn{3}{|c|}{$\mathrm{MDA}\left[\mathrm{nmol} \cdot \mathrm{ml}^{-1}\right]$} \\
\hline & \multicolumn{2}{|c|}{$\begin{array}{l}\text { group } \\
\text { grupa }\end{array}$} & \multirow[t]{2}{*}{ SEM } & \multicolumn{2}{|c|}{$\begin{array}{l}\text { group } \\
\text { grupa }\end{array}$} & \multirow[t]{2}{*}{ SEM } \\
\hline & 1 & II & & 1 & II & \\
\hline 35 & 0.284 & 0.283 & 0.017 & $1.345^{\mathrm{Aa}}$ & $1.327^{\mathrm{Aa}}$ & 0.132 \\
\hline 39 & 0.240 & 0.270 & 0.018 & $1.567^{b}$ & $1.534^{b}$ & 0.147 \\
\hline 42 & 0.240 & 0.268 & 0.016 & $1.602^{\mathrm{B}}$ & $1.625^{\mathrm{B}}$ & 0.176 \\
\hline
\end{tabular}

Explanations as in Table 3 - Objaśnienia jak w tab. 3.

Statistically significant differences in SOD (Table 5) and CAT activity (Table 6) were observed in the breast and leg muscles only in group I. SOD activity in the breast and leg muscles was statistically significantly higher $(P \leq 0.05)$ on day 39 as compared to day 35 (breast muscles), and on day 39 compared to days 35 and 42 (leg muscles). The highest CAT activity, both for the breast muscles $(P \leq 0.01)$ and the legs $(P \leq 0.05)$, was recorded on day 39. In addition, statistically significant differences $(P \leq 0.05)$ on this day were observed in CAT activity in the breast muscles between groups. The only statistically significant differences in the GPx activity (Table 7 ) were observed in leg muscles from group II between 35 and 39 days of experiment $(P \leq 0.05)$.

Both groups showed a decrease in the level of GSH (Table 8) and an increase in the level of MDA (Table 9) under the influence of high temperatures, in both the breast and leg muscles. Statistically significant differences in GSH levels were observed only in group I in breast muscles $(P \leq 0.05)$. On the other hand, statistically the highest MDA level $(P \leq 0.01)$ was recorded on day 42 of the study in leg muscles of both groups. 
Table 5. SOD activity in breast and leg muscles

Tabela 5. Aktywność SOD w mięśniach piersiowych i nóg

\begin{tabular}{|c|c|c|c|c|c|c|}
\hline \multirow{4}{*}{$\begin{array}{l}\text { Day of } \\
\text { rearing } \\
\text { Dzień } \\
\text { odchowu }\end{array}$} & \multicolumn{3}{|c|}{ Breast muscles - Mięśnie piersiowe } & \multicolumn{3}{|c|}{ Leg muscles - Mięśnie nóg } \\
\hline & \multicolumn{6}{|c|}{ SOD $\left[\mathrm{U} \cdot \mathrm{mg}^{-1}\right.$ protein - białka $]$} \\
\hline & \multicolumn{2}{|c|}{ group - grupa } & \multirow{2}{*}{ SEM } & \multicolumn{2}{|c|}{ group - grupa } & \multirow{2}{*}{ SEM } \\
\hline & 1 & II & & 1 & II & \\
\hline 35 & $1.592 \mathrm{a}$ & 3.194 & 0.911 & $1.418 a$ & 2.302 & 0.838 \\
\hline 39 & $5.114 b$ & 4.428 & & $4.532 b$ & 4.826 & \\
\hline 42 & 2.332 & 2.431 & & $1.776 \mathrm{a}$ & 2.442 & \\
\hline
\end{tabular}

Explanations as in Table 3 - Objaśnienia jak w tab. 3.

Table 6. CAT activity in breast and leg muscles

Tabela 6. Aktywność CAT w mięśniach piersiowych i nóg

\begin{tabular}{|c|c|c|c|c|c|c|}
\hline \multirow{4}{*}{$\begin{array}{l}\text { Day of } \\
\text { rearing } \\
\text { Dzień } \\
\text { odchowu }\end{array}$} & \multicolumn{3}{|c|}{ Breast muscles - Mięśnie piersiowe } & \multicolumn{3}{|c|}{ Leg muscles - Mięśnie nóg } \\
\hline & \multicolumn{6}{|c|}{ CAT $\left[\mathrm{U} \cdot \mathrm{mg}^{-1}\right.$ protein - białka $]$} \\
\hline & \multicolumn{2}{|c|}{ group - grupa } & \multirow{2}{*}{ SEM } & \multicolumn{2}{|c|}{ group - grupa } & \multirow{2}{*}{ SEM } \\
\hline & I & II & & I & II & \\
\hline 35 & $9.898 \mathrm{~A}$ & 8.851 & 2.059 & 8.607 & 14.611 & 2.941 \\
\hline 39 & $18.386 \mathrm{Bb}^{*}$ & $10.411^{*}$ & & $17.247 \mathrm{~b}$ & 15.525 & \\
\hline 42 & $11.971 \mathrm{a}$ & 7.054 & & $7.716 \mathrm{a}$ & 13.850 & \\
\hline
\end{tabular}

Explanations as in Table 3 - Objaśnienia jak w tab. 3.

Table 7. GPx activity in breast and leg muscles

Tabela 7. Aktywność GPx w mięśniach piersiowych i nóg

\begin{tabular}{|c|c|c|c|c|c|c|}
\hline \multirow{4}{*}{$\begin{array}{l}\text { Day of } \\
\text { rearing } \\
\text { Dzień } \\
\text { odchowu }\end{array}$} & \multicolumn{3}{|c|}{ Breast muscles - Mięśnie piersiowe } & \multicolumn{3}{|c|}{ Leg muscles - Mięśnie nóg } \\
\hline & \multicolumn{6}{|c|}{$\mathrm{GPx}\left[\mathrm{U} \cdot \mathrm{mg}^{-1}\right.$ protein - białka $]$} \\
\hline & \multicolumn{2}{|c|}{ group - grupa } & \multirow{2}{*}{ SEM } & \multicolumn{2}{|c|}{ group - grupa } & \multirow{2}{*}{ SEM } \\
\hline & 1 & II & & I & II & \\
\hline 35 & 0.020 & 0.028 & 0.003 & 0.038 & $0.066 \mathrm{~b}$ & 0.011 \\
\hline 39 & 0.028 & 0.031 & & 0.020 & $0.024 \mathrm{a}$ & \\
\hline 42 & 0.023 & 0.026 & & 0.027 & 0.044 & \\
\hline
\end{tabular}

Explanations as in Table 3 - Objaśnienia jak w tab. 3.

Table 8. Level of GSH in breast and leg muscles

Tabela 8. Stężenie GSH w mięśniach piersiowych i nóg

\begin{tabular}{|c|c|c|c|c|c|c|}
\hline \multirow{4}{*}{$\begin{array}{l}\text { Day of } \\
\text { rearing } \\
\text { Dzień } \\
\text { odchowu }\end{array}$} & \multicolumn{3}{|c|}{ Breast muscles - Mięśnie piersiowe } & \multicolumn{3}{|c|}{ Leg muscles - Mięśnie nóg } \\
\hline & \multicolumn{6}{|c|}{ GSH $\left[\mu \mathrm{mol} \cdot \mathrm{g}^{-1}\right.$ protein - białka $]$} \\
\hline & \multicolumn{2}{|c|}{ group - grupa } & \multirow{2}{*}{ SEM } & \multicolumn{2}{|c|}{ group - grupa } & \multirow{2}{*}{ SEM } \\
\hline & 1 & II & & 1 & II & \\
\hline 35 & $3.195 \mathrm{~b}$ & 2.497 & 0.435 & 7.020 & 1.277 & 1.109 \\
\hline 39 & $1.758 \mathrm{a}$ & 2.664 & & 4.362 & 1.206 & \\
\hline 42 & $1.438 \mathrm{a}$ & 1.774 & & 3.196 & 1.185 & \\
\hline
\end{tabular}

Explanations as in Table 3 - Objaśnienia jak w tab. 3.

Table 9. Level of MDA in breast and leg muscles

Tabela 9. Stężenie MDA w mięśniach piersiowych i nóg

\begin{tabular}{|c|c|c|c|c|c|c|}
\hline \multirow{4}{*}{$\begin{array}{l}\text { Day of } \\
\text { rearing } \\
\text { Dzień } \\
\text { odchowu }\end{array}$} & \multicolumn{3}{|c|}{ Breast muscles - Mięśnie piersiowe } & \multicolumn{3}{|c|}{ Leg muscles - Mięśnie nóg } \\
\hline & \multicolumn{6}{|c|}{ MDA $\left[\mathrm{nmol} \cdot \mathrm{mg}^{-1}\right.$ protein - białka] } \\
\hline & \multicolumn{2}{|c|}{ group - grupa } & \multirow{2}{*}{ SEM } & \multicolumn{2}{|c|}{ group - grupa } & \multirow{2}{*}{ SEM } \\
\hline & $\mathrm{I}$ & II & & $\mathrm{I}$ & II & \\
\hline 35 & 3.188 & 3.563 & 0.686 & $2.625 \mathrm{~A}$ & $3.313 \mathrm{~A}$ & 0.582 \\
\hline 39 & 3.750 & 4.000 & & $4.375 \mathrm{~A}$ & $4.125 \mathrm{~A}$ & \\
\hline 42 & 5.375 & 5.375 & & $7.125 \mathrm{~B}$ & $6.813 \mathrm{~B}$ & \\
\hline
\end{tabular}

Explanations as in Table 3 - Objaśnienia jak w tab. 3. 


\section{DISCUSSION}

Continuous selection of broiler chickens for rapid growth and greater weight resulted in sensitization of these birds to thermal conditions (Washburn et al. 1980; Cahaner et al. 1995; Berrong and Washburn 1998). High ambient temperature decreased the broiler performance (Ali et al. 2010; Rashidi et al. 2010), particularly the feed consumption and growth rate (El-Habbak et al. 2011). Antioxidant status of the organism is activated as a response to heat-induced oxidative stress. In broiler chickens, oxidative injury, induced by high ambient temperatures, has been demonstrated in previous in vivo and in vitro studies (Sahin et al. 2001; Altan et al. 2003; Mujahid et al. 2005, 2006, 2007; Lin et al. 2006, 2008).

Oxidative stress is caused by reactive oxygen species (ROS), which produced due to leakage of electron from the respiratory chain during the reduction of molecular oxygen to water generating superoxide anion in chicken (Mujahid et al. 2005; Lu et al. 2010). Heat stress can disturb the balance between the production of ROS and the antioxidant systems, and may further stimulate the formation of ROS (Mahmoud and Edens 2003; Lin et al. 2006; Feng et al. 2008). Superfluous ROS induced by heat stress can cause oxidative injury, such as lipid peroxidation and oxidative damage to proteins and DNA (Halliwell and Aruoma 1991; Mujahid et al. 2007).

The enzymatic or non-enzymatic antioxidant systems of the body are responsible for scavenging of these ROS, protecting DNA and macromolecules from deterioration (Lu et al. 2010). Glutathione, selenium, Vitamin $\mathrm{C}$ and $\mathrm{E}$ are the main non-enzymatic antioxidants whereas, SOD, CAT and GPx are the major antioxidant enzymes (Cadenas and Davies 2000).

In our studies, it was found that under the influence of the elevated ambient temperature, the antioxidant system was activated. This reflects the increase in antioxidant enzyme activity in both serum and breast and leg muscles. It is worth noting that larger changes in enzyme activity have been observed in birds kept on litter without the use of paddocks. Birds maintained with green paddocks were characterized by more stable enzymatic activity. Also in group I, during the elevated air temperature, a greater decrease of GSH in serum and muscle was observed. The activity of the antioxidant system could have been influenced by the way the birds were kept - birds in group II were able to protect themselves in shady and airy spots on the paddocks, which could have affected their greater thermal comfort and wellbeing.

One of the most important biological processes associated with ROS is lipid peroxidation (Yagi 1992). Lipid peroxidation is the avalanche, free radical oxidation process of the lipid, present in unsaturated fatty acids, in which the peroxides of these compounds are formed. Peroxidation predominantly undergone by polyunsaturated fatty acid residues, which are a part of phospholipids, which, in turn, are the major building blocks of the cell membranes (McConnell et al. 1999). One of the many compounds produced by the peroxidation process of polyunsaturated fatty acids is malondialdehyde (MDA).

The levels of MDA in serum and tissues were used as biomarkers of lipid peroxidation (Sehirli et al. 2008; Yousef et al. 2009; Ismail et al. 2013) and MDA level is directly proportional to the degree of lipid peroxidation (Kuhn and Borchert 2002; Ismail et al. 2013).

In our studies, under the influence of high temperatures, elevated MDA levels were observed both in muscles and serum in both groups. However, interestingly, statistically 
significant changes in MDA levels were observed in serum and leg muscles, but in breast muscles these changes were not statistically significant. This could indicate that the leg muscles are more prone to damage associated with oxidative stress caused by high ambient temperatures than the breast muscles. We should also remember that MDA is produced by the action of free radicals inside the body (Long et al. 2009), as well as in products of animal origin containing fats (Okafor et al. 2007; Okolie et al. 2009). It is also important from the point of view of food safety that the freezing of raw meat material only slightly inhibits the peroxidation process (Okolie et al. 2009). This is because the solubility of free lipid radicals in the lipid fraction increases at low temperatures, so that they diffuse over long distances, inducing lipid oxidation reactions during storage (Kanner 1994).

\section{CONCLUSIONS}

The increase in antioxidant enzyme activity and decrease in the level of GSH in both serum and breast and leg muscles suggest that the elevated air temperature initiates oxidative stress in broiler chickens, regardless of the rearing system. However, larger changes in enzymes activity and GSH level have been observed in birds kept on litter without the use of paddocks. Broiler chickens using green paddocks were characterized by a more stable antioxidant system. Probably, shady and airy spots on the paddocks guaranteed them better thermal comfort which affect their welfare. The results also indicate that leg muscles are more sensitive to the effects of oxidative stress than breast muscles, as indicated by the MDA level.

\section{REFERENCES}

Aebi H.E. 1984. Catalase, in: Methods of enzymatic analysis. Vol. 3. Ed. H.U. Bergmeyer. New York, Wiley. 273-286.

Ali M.N., Qota E.M.A., Hassan R.A. 2010. Recovery from adverse effects of heat stress on slowgrowing chicks using natural antioxidants without or with sulphate. Int. J. Poultry Sci. 9(2), 109-117.

Altan Ö., Pabuçcuoğlu A., Altan A., Konyalioğlu S., Bayraktar H. 2003. Effect of heat stress on oxidative stress, lipid peroxidation and some stress parameters in broilers. Brit. Poultry Sci. 44(4), $545-550$.

Berrong S.L., Washburn K.W. 1998. Effect of genetic variation on total plasma protein, body weight gains, and body temperature responses to heat stress. Poultry Sci. 77, 379-385.

Bradford M.M. 1976. A rapid and sensitive method for the quantitation of microgram quantities of protein utilizing the principle for protein-dye binding. Anal. Biochem. 72, 248-254.

Cadenas E., Davies K.J. 2000. Mitochondrial free radical generation oxidative stress and aging. Free Radic. Biol. Med. 29, 222-230.

Cahaner A., Pinchasov Y., Nir I., Nitsan Z. 1995. Effects of dietary protein under high ambient temperature on body weight, breast meat yield, and abdominal fat deposition of broiler stocks differing in growth rate and fatness. Poultry Sci. 74, 968-975.

El-Habbak M.M., El-Ghamry A.A., EI-Mallah G.M., Younis H.H., El-Komy E.M. 2011. Influence of dietary vitamin $E$ and $C$ supplementation on performance and some metabolic response of broiler chicks subjected to heat stress. World J. Agric. Sci. 7, 258-269.

Ellman G.L. 1959. Tissue sulfhydryl groups. Arch. Biochem. Biophys. 82, 70-77.

Feng J., Zhang M., Zheng S., Xie P., Ma A. 2008. Effects of high temperature on multiple parameters of broilers in vitro and in vivo. Poultry Sci. 87, 2133-2139. 
Food and Agriculture Organization/World Health Organization. 1991. Protein quality evaluation: report of the Joint FAO/WHO Expert Consultation. FAO Food Nutrit. Pap. 51, 30-41

Halliwell B., Aruoma O.I. 1991. DNA damage by oxygenderived species. Its mechanism and measurement in mammalian systems. FEBS Lett. 281, 9-19.

Ismail I.B., Al-Busadah K.A., El-Bahr S.M. 2013. Oxidative stress biomarkers and biochemical profile in broilers chicken fed zinc bacitracin and ascorbic acid under hot climate. Am. J. Biochem. Mol. Biol. 3, 202-214.

Kanner J. 1994. Oxidative processes in meat and meat products: quality implications. Meat Sci. 36, 169-189.

Kitessa S.M., Young P. 2009. Echium oil is better than rapeseed oil in enriching poultry with $n-3$ PUFA, including eicosapentaenoic acid and docosapentaenoic acid. Brit. J. Nutr. 101, 709-715.

Kuhn H., Borchert A. 2002. Regulation of enzymatic lipid peroxidation: The interplay of peroxidizing and peroxide reducing enzymes. Free Radical Biol. Med. 33, 154-172.

Lara L.J., Rostagno M.H. 2013. Impact of heat stress on poultry production. Animals 3(2), 356-369.

Lin H., De Vos D., Decuypere E., Buyse J. 2008. Dynamic changes in parameters of redox balance after mild heat stress in aged laying hens (Gallus gallus domesticus). Comp. Biochem. Physiol. C, Toxicol. Pharmacol. 147, 30-35.

Lin H., Decuypere E., Buyse J. 2006. Acute heat stress induces oxidative stress in broiler chickens. Comp. Biochem. Physiol. A 144, 11-17.

Long J., Liu C., Sun L., Gao H., Liu J. 2009. Neuronal mitochondrial toxicity of malondialdehyde: inhibitory effects on respiratory function and enzyme activities in rat brain mitochondria. Neurochem Res. 34(4), 786-94.

Lu T., Piao X.L., Zhang Q., Wang D., Piao X.S., Kim S.W. 2010. Protective effects of Forsythia suspensa extract against oxidative stress induced by diquat in rats. Food Chem. Toxicol. 48(2), 764-770.

Lück H. 1962. Peroxidase, in: Methoden der enzymatischen analyse. Weinheim, Verlag Chemie, GMBH, 895-897.

Mahmoud K.Z., Edens F.W. 2003. Influence of selenium sources on age-related and mild heat stress-related changes of blood and liver glutathione redox cycle in broiler chickens (Gallus domesticus). Comp. Biochem. Physiol., B Biochem. Mol. Biol. 136, 921-934.

McConnell E.J., Bittelmeyer A.M., Raess B.U. 1999. Irreversible inhibition of plasma membrane $\left(\mathrm{Ca}^{2+}+\mathrm{Mg}^{2+}\right)$-ATPase and $\mathrm{Ca}^{2+}$ transport by 4-OH-2,3-trans-nonenal. Arch. Biochem. Biophys. 361, 252-256.

Muchacka R., Kapusta E., Skomorucha I., Sosnówka-Czajka E. 2016. Aktywność enzymów antyoksydacyjnych oraz poziom GSH i MDA w osoczu, wątrobie i nerkach kurcząt brojlerów utrzymywanych $\mathrm{w}$ różnych systemach odchowu $\mathrm{w}$ letnim cyklu produkcyjnym $\mathrm{w}$ warunkach podwyższonej temperatury otoczenia [Antioxidant enzymes activity and levels of GSH and MD A in plasma, liver and kidney of broiler chickens reared in different systems during the summer production cycle and exposed to high ambient temperature]. Rocz. Nauk. Zoot. 43(2), 245-255. [in Polish]

Mujahid, A., Pumford N.R., Bottje W., Nakagawa K., Miyazawa T., Akiba Y., Toyomizu M. 2007. Mitochondrial oxidative damage in chicken skeletal muscle induced by acute heat stress. Jpn. Poultry Sci. 44, 439-445.

Mujahid, A., Sato K., Akiba Y., Toyomizu M. 2006. Acute heat stress stimulates mitochondrial superoxide production in broiler skeletal muscle, possibly via downregulation of uncoupling protein content. Poultry Sci. 85, 1259-1265.

Mujahid, A., Yoshiki Y., Akiba Y., Toyomizu M. 2005. Superoxide radical production in chicken skeletal muscle induced by acute heat stress. Poultry Sci. 84, 307-314.

Ohkawa H., Ohishi N., Yagi K. 1979. Assay for lipid peroxides in animal tissues by thiobarbituric acid reaction. Anal. Biochem. 95, 351-358. 
Okafor P.N., Nwosu O., Chukwu J., Agbayi J., Maduagwu E.N. 2007. Occurrence of malondialdehyde and $\mathrm{N}$-nitrosamines and their precursors in some Nigerian ice creams, yogurts, meat and fish species. Afr. J. Biochem. Res. 1(1), 001-005.

Okolie N.P., Akioyamen M.O., Okpoba N., Okonkwo C. 2009. Malondialdehyde levels of frozen fish, chicken and turkey on sale in Benin City markets. Afr. J. Biotechnol. 8(23), 6638-6640.

Pietrzak D., Mroczek J., Antolik A., Michalczuk M., Niemiec J. 2005. Wpływ rodzaju stymulatora wzrostu dodawanego do paszy na jakość mięsa i tłuszczu kurcząt [The influence of the type of growth stimulator added to the feed on the quality of meat and fat of chickens]. Med. Weter. 61, 553-557. [in Polish]

Pikul J. 2009. Lipidy mięsa drobiowego, w: Przetwórstwo mięsa drobiu - podstawy biologiczne i technologiczne. Red. T. Smolińska, W. Kopeć. Wrocław, Wydaw. UP, 149-177. [in Polish]

Rashidi A.A., Ivari Y.G., Khatibjoo A., Vakili R. 2010. Effects of dietary fat, vitamin E and zinc on immune response and blood parameters of broiler reared under heat stress. Res. J. Poultry Sci. 3(2), 32-38.

Rice-Evans C.A., Diplock A.T., Symons M.C.R. 1991. Techniques in free radical research, in: Laboratory techniques in biochemistry and molecular biology. Ed. R.H. Burdon, van P.H. Knippenberg. Amsterdam, Elsevier, 22, 1-278.

Rozporządzenie Ministra Rolnictwa i Rozwoju Wsi z dnia 15 lutego 2010 r. w sprawie wymagań i sposobu postępowania przy utrzymywaniu gatunków zwierząt gospodarskich, dla których normy ochrony zostały określone w przepisach Unii Europejskiej. DzU z 15.02.2010, nr 56, poz. 344. [in Polish]

Sahin K., Sahin N., Onderci M., Yaralioglu S., Kucuk O. 2001. Protective role of supplemental vitamin $\mathrm{E}$ on lipid peroxidation, vitamins $\mathrm{E}, \mathrm{A}$ and some mineral concentrations of broilers reared under heat stress. Vet. Med. - Czech. 46, 140-144.

Sehirli O., Tozan A., Omurtag G.Z., Cetinel S., Contuk G., Gedik N., Sener G. 2008. Protective effect of resveratrol against naphthalene-induced oxidative stress in mice. Ecotoxicol. Environ. Saf. 71, 301-308.

Simopoulos A.P. 1999. Essential fatty acids in health and chronic disease. Am. J. Clin. Nutr. 70, 560-569.

Washburn K.W., Peavey R., Renwick G.M. 1980. Relationship of strain variation and feed restriction to variation in blood pressure and response to heat stress. Poultry Sci. 59, 2586-2588.

Woźniak E., Banaszewska D., Biesiada-Drzazga B. 2016. Health-promoting properties of poultry meat in the context of diseases of civilization. Folia Pomer. Univ. Technol. Stetin., Agric., Aliment., Pisc., Zootech. 328(39)3, 235-246.

Yagi K. 1992. Lipid peroxides and exercise. Med. Sci. Sport Sci. 21, 37-40.

Yousef M.I., Saad A.A., El-Shennawy L.K. 2009. Protective effect of grape seed proanthocyanidin extract against oxidative stress induced by cisplatin in rats. Food Chem. Toxicol. 47, 1176-1183.

Zhang Z.Y., Jia G.Q., Zuo J.J., Zhang Y., Lei J., Ren L., Feng D.Y. 2012. Effects of constant and cyclic heat stress on muscle metabolism and meat quality of broiler breast fillet and thigh meat. Poultry Sci. 91(11), 2931-2937.

Abstract. The aim of the study was to investigate possible oxidative damage in serum, breast and leg muscles in broiler chickens Ross 308 reared in two housing systems and exposed to high summer air temperature. 400 broiler chickens were divided into two groups (200 birde per group): I - birds kept on litter in an indoor system, II - chickens kept on litter with access to green paddocks. Birds were fed ad libitum standard diets based on concentrates. Throughout the study, birds had free access to water. Both groups were managed under uniform environmental (air humidity and temperature, lighting programme) and feeding conditions. In the 6th week of rearing, during high outdoor temperatures, antioxidant enzymes activity (CAT, SOD, $\mathrm{GPx}$ ), glutathione (GSH) and malondialdehyde (MDA) concentrations in serum, breast and leg 
muscles tissues were investigated. In addition, blood and tissue samples were collected 1 day before high summer outdoor temperatures. The results showed that elevated air temperature initiates oxidative stress in broiler chickens, regardless of rearing system, but broiler chickens using green paddocks were characterized by a more stable antioxidant system. High air temperatures initiate lipid peroxidation as indicated by increased MDA levels, however leg muscles are more sensitive to the effect of oxidative stress than breast muscles. 
